\title{
Attachment of Treponema pallidum to fibronectin, laminin, collagen IV, and collagen I, and blockage of attachment by immune rabbit IgG
}

\author{
T J FITZGERALD,* L A REPESH, † D R BLANCO, $\neq$ AND J N MILLER \\ From the Departments of Medical Microbiology and Immunology and + Biomedical Anatomy, School of \\ Medicine, University of Minnesota, Duluth, Minnesota, and the $¥$ Department of Microbiology and \\ Immunology, School of Medicine, University of California at Los Angeles, Los Angeles, California, USA
}

SUMMARY As shown by scanning electron and phase contrast microscopy, Treponema pallidum attached in vitro to basement membranes purified from kidney cortex tissues or from retinal vessels. This organism also attached to the extracellular matrix remaining after cultured cells had been solubilised with Triton X. Fibronectin, laminin, collagen, IV, collagen I, and hyaluronic acid are structural components of basement membranes and extracellular matrices. Experiments were performed to investigate the in vitro attachment of $T$ pallidum to each of these components. Viable or heat inactivated treponemes were added to glass coverslips precoated with different concentrations of each component. After various times of incubation, coverslips were washed and the attached organisms were counted. Large numbers of viable organisms attached to each of these five components. In contrast, heat inactivation sharply reduced numbers of attached organisms. The IgG fractions of immune and non-immune rabbit serum samples were affinity purified using protein A. T pallidum was preincubated with both fractions, then incubated with either intact cultured cells or with coverslips coated with the five tissue components. The IgG from immune serum blocked treponemal attachment to the cultured cells and to fibronectin, laminin, collagen IV, and collagen I, but not to hyaluronic acid. These results are discussed in terms of attachment mechanisms of $T$ pallidum and potential applications to in vivo infection.

\section{Introduction}

Attachment to host tissues appears to be a necessary step in causing many bacterial infections, ${ }^{1}$ including syphilis. ${ }^{2-4}$ Treponema pallidum readily attaches to numerous different types of cultured mammalian cells. $^{23} \mathrm{~s}$ This in vitro model has been used to identify mechanisms of syphilitic pathogenesis and host immune responses. ${ }^{2}$ Treponema pertenue, the causative agent of yaws, also attaches to cultured cells, ${ }^{6}$ whereas non-pathogenic treponemes do not. These observations point to cellular attachment as a pathogenic capability. ${ }^{37}$ In addition, immune rabbit serum contains factors that block treponemal attachment to cultured cells ${ }^{4}$; this blockage may be an important component of the healing process. ${ }^{7}$

Address for reprints: Dr T J Fitzgerald, Department of Medical Microbiology and Immunology, School of Medicine, University of Minnesota, Duluth, Minnesota 55812, USA

Accepted for publication 15 April 1984
Within infected tissues $T$ pallidum localises primarily in perivascular areas, either closely adjacent to the basement membrane of vessels or within the surrounding extracellular matrix (ground substance). Fibronectin, laminin, collagen IV, collagen I, and hyaluronic acid are structural components of both basement membranes and extracellular matrices. ${ }^{8-11}$ Each of these five components is also produced in vitro by different types of cultured cells. ${ }^{8}{ }^{10-15}$ We have shown in preliminary experiments that fibronectin is associated with the surface of $T$ pallidum, and that preincubation with antifibronectin partly blocks treponemal attachment to cultured cells (UCLA symposium on the Molecular Biology of Host-Parasite Interactions, January, 1983).

The purpose of this research was to investigate the attachment of $T$ pallidum to fibronectin, laminin, collagens, and hyaluronic acid and to determine the effects of antibodies in blocking attachment. Other workers have reported that fibronectin binds to 
staphylococci, ${ }^{16}$ groups A, C, and G streptococci, ${ }^{17} 18$ and Candida albicans. ${ }^{19}$

\section{Materials and methods}

\section{T PALLIDUM}

Dutch belt rabbits weighing $2-2 \cdot 2 \mathrm{~kg}$ were inoculated intratesticularly with $30-50 \times 10^{6}$ treponemes per testis. The animals were given daily intramuscular injections of cortisone acetate (Merck Sharpe and Dohme, West Point, Pennsylvania, USA) at $6 \mathrm{mg} / \mathrm{kg}$ body weight. Rabbits were killed after six to nine days by intracardiac injection of pentobarbitol. Testes were removed asceptically, rinsed in $0.14 \mathrm{~mol} / \mathrm{l}$ saline, placed in medium, and sliced with scissors. Organisms were extracted aerobically on a rotary shaker for 15 to 20 minutes at $23^{\circ} \mathrm{C}$ in McCoy's 5A medium supplemented with $1 \mathrm{mmol} / 1$ diothiothreitol, $10 \%$ normal rabbit serum (heated at $56^{\circ} \mathrm{C}$ for 30 minutes), and $30 \mathrm{mmol} / 1 \mathrm{~N}-2$-hydroxy-

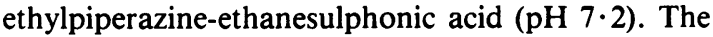
resulting suspension was centrifuged for 7 minutes at $1000 \times g$ at $23^{\circ} \mathrm{C}$ to sediment gross particulate debris. The organisms in the supernatant were adjusted with extraction medium to $20 \times 10^{6}$ treponemes $/ \mathrm{ml}$ using a Petroff-Hausser counting chamber. In some experiments $T$ pallidum was heat inactivated at $56^{\circ} \mathrm{C}$ for 10 minutes. Treponemes were incubated at $37^{\circ} \mathrm{C}$ in an atmosphere containing $2.5 \%$ oxygen, $5 \%$ carbon dioxide, and $92 \cdot 5 \%$ nitrogen.

\section{ATTACHMENT ASSAYS}

Techniques are well established for assessing attachment of cancer cells to various tissue components coated on glass or plastic. ${ }^{14}{ }^{20-22}$ Two methods were used to coat components on to glass coverslips in Sykes-Moore chambers. ${ }^{23}$ In the early experiments $1 \mathrm{ml}$ fibronectin or laminin was added to the chambers. After two hours at $37^{\circ} \mathrm{C}$ in a humidified atmosphere, the chambers were washed five times with $1 \mathrm{ml}$ phosphate buffered saline (PBS) to remove non-adherent fibronectin or laminin. In later experiments designed to conserve individual components, $100 \mu \mathrm{l}$ fibronectin, laminin, collagen IV, collagen I, or hyaluronic acid were evenly spread on to the coverslips and air dried. After coating the coverslips by either method $20 \times 10^{6}$ organisms $/ \mathrm{ml}$ were added, and chambers were incubated at $37^{\circ} \mathrm{C}$ in the reduced oxygen atmosphere. After incubation the coverslips were removed from the chambers and each dipped three times into three separate beakers containing $100 \mathrm{ml}$ PBS to remove unattached organisms. Coverslips were placed on a slide and the number of attached organisms was estimated by counting at least 20 fields at a magnification of $\times 400$.

\section{SERUUM SAMPLES}

Pooled normal rabbit serum was obtained from three uninfected animals; pooled immune rabbit serum was obtained from three previously infected animals shown to be resistant to intradermal challenge with $100 \times 10^{6}$ treponemes administered at monthly intervals over a two year period. Serum samples were heat inactivated at $56^{\circ} \mathrm{C}$ for 30 minutes. The IgG fractions of normal or immune rabbit serum were prepared as follows. Serum was diluted $1 / 2$ with $0.14 \mathrm{~mol} / \mathrm{l}$ phosphate buffer $(\mathrm{pH} 8 \cdot 0)$ and loaded on to a staphylococcal protein A-sepharose $4 \mathrm{~B}$ affinity column. Unbound serum proteins were removed with the phosphate buffer, and IgG was eluted with $0.1 \mathrm{~mol} / 1$ citrate buffer $(\mathrm{pH} \mathrm{3.5)}$. To neutralise the effluent, fractions were collected in $1 \mathrm{~mol} / 1$ trometamol (TRIS)-hydrochloric acid buffer ( $\mathrm{pH}$ $9 \cdot 0)$. Fractions containing IgG were shown spectrophotometrically $(280 \mathrm{~nm})$ and quantified by measuring the optical density of the pooled fractions using an extinction coefficient of $14(1 \% \mathrm{w} / \mathrm{v} ; 1 \mathrm{~cm})$. The IgG fraction was filter sterilised, transferred to a sterile dialysis bag, and dialysed against PBS pH $7 \cdot 2$ for 24 hours at $4^{\circ} \mathrm{C}$ to remove the citrate and TRIShydrochloric acid buffers. The dialysed fraction was concentrated approximately 10-fold by pervaporation and redialysed against PBS for two hours at $4^{\circ} \mathrm{C}$. The purity of the IgG was confirmed using immunoelectrophoresis and sodium dodecyl sulphate polyacylamide gel electrophoresis (SDSPAGE) techniques (Blanco, Miller, and Hanff, unpublished observation). The isolated IgG fractions were lyophilised and stored at $4^{\circ} \mathrm{C}$.

For blockage experiments, our previously published protocol was used. ${ }^{7}$ A volume of $3 \mathrm{ml}$ of treponemes at $60 \times 10^{6}$ organisms $/ \mathrm{ml}$ was added to $3 \mathrm{ml}$ undiluted normal or immune rabbit serum previously heated to inactivate complement. The final serum concentration was therefore $55 \%(50 \%$ added normal or immune rabbit serum plus $10 \%$ serum in the extraction medium). These suspensions were pre-incubated for 18 hours at $37^{\circ} \mathrm{C}$ in an atmosphere of reduced oxygen to permit optimal antibody reactivity with treponemal antigens. Both treponemal preparations were then added to cultured cells or to glass coverslips coated with fibronectin, laminin, collagen IV, collagen I, or hyaluronic acid. After two hours at $37^{\circ} \mathrm{C}$ in reduced oxygen, the coverslips were washed and the attached treponemes were counted. Similar procedures were followed to show blockage by the IgG from normal or immune rabbit serum, the only difference being the final serum concentration. A volume of $3 \mathrm{ml}$ of organisms suspended in the extraction medium, which contained $10 \%$ heated rabbit serum, was added to $3 \mathrm{ml}$ of the respective IgG fractions from normal or immune rabbit serum. The final serum concentration 
was therefore 5\%. (Without this added serum, treponemes could not survive for the required 18 hours of preincubation.)

\section{CHEMICALS}

Affinity purified fibronectin, affinity purified laminin, hyaluronic acid, and bovine serum albumin were obtained from Sigma Chemical (St Louis, Missouri, USA) and collagen I and IV from Calbiochem Company (San Diego, California, USA). Fibronectin, laminin, and both collagens were solubilised according to the commercially provided instructions. Appropriate dilutions were made using PBS pH 7·2. Hyaluronic acid was dissolved in PBS and then adjusted to $\mathrm{pH} 7 \cdot 2$ using $1 \mathrm{~mol} / 1$ sodium hydroxide. All five components were used immediately or aliquoted and frozen at $-70^{\circ} \mathrm{C}$. The coverslips were freshly coated with samples just before each experiment.

\section{Results}

We have previously shown that $T$ pallidum attaches in vitro to isolated capillary tissues. ${ }^{23}$ Histological sections showed an intact basement membrane on the outer surface of these capillaries (Fitzgerald T J, Repesh L A, unpublished findings), suggesting specific treponemal interaction with basement membrane components. To confirm this possibility, experiments were performed using purified basement membranes isolated from rat kidney cortex or rat retinal vessels (kindly provided by Dr Ed Carlson, Department of Anatomy, University of North Dakota). Treponemes were added to both preparations, and observations were made with phase contrast and scanning electron microscopy. Large numbers of organisms attached to both basement membrane preparations. Figures 1(a) and (b) show electron micrographs of treponemes attached to these membranes. Attachment of actively motile treponemes was identical to that previously described for cultured cells ${ }^{325}$ and for isolated capillaries. ${ }^{24}$ Organisms attached at their ends and remained actively motile.

Cultured mammalian cells secrete an extracellular matrix that, depending on the cell type, contains fibronectin, laminin, collagens, hyaluronic acid, or a combination of these components. ${ }^{8}{ }^{10-15}$ Treatment of cultured cells with Triton $\mathrm{X}$ disrupts cellular membranes leaving the extracellular matrix on the surface of the culture vessel. ${ }^{13}$ To ascertain whether $T$ pallidum attached directly to components of the extracellular matrix, cells cultured from human epidermal carcinoma (Hep 2), rabbit kidney, rabbit dermis, and rabbit testis were grown to confluency and then treated with Triton $\mathrm{X}$. The subsequent
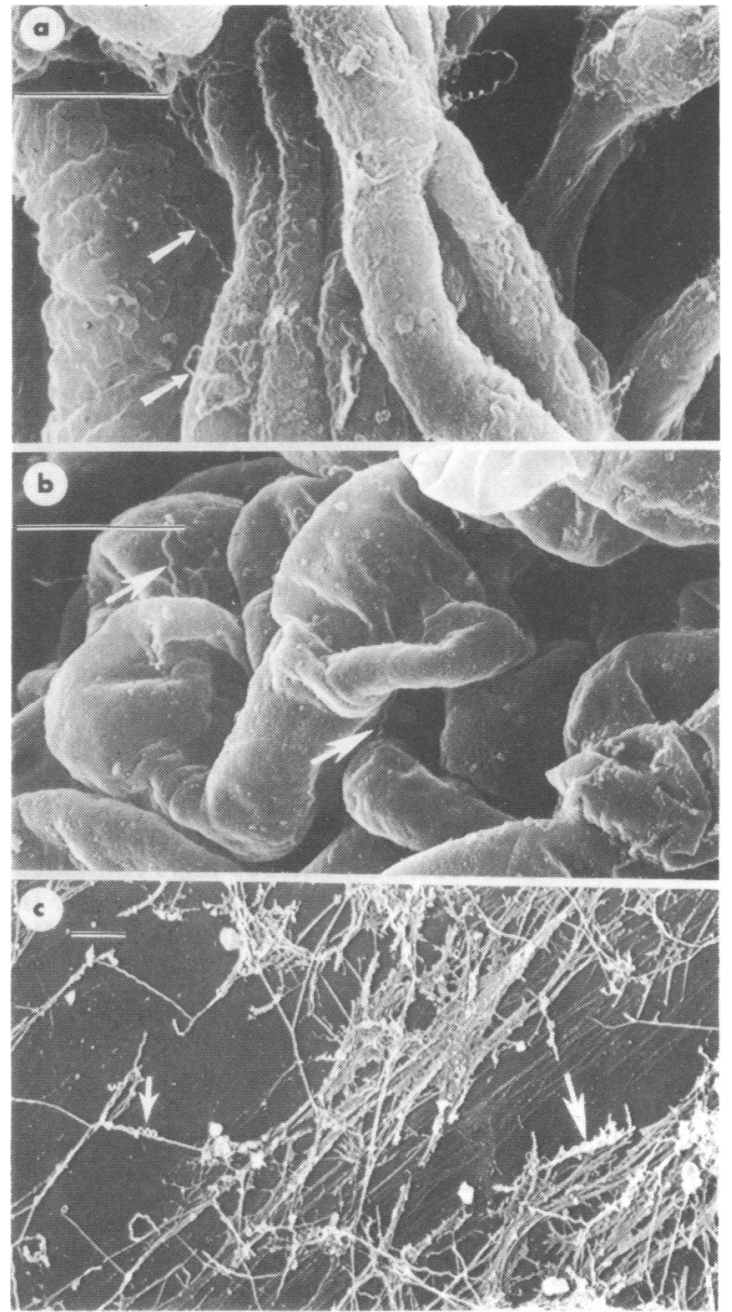

FIGURE Scanning electron micrograph of $T$ pallidum (arrows) attached to: (a) purified basement membranes from retinal vessels, (b) purified basement membranes from kidney cortex, (c) extracellular matrix of cultured rabbit testicular cells after treatment with Triton $X$. (Bars represent $25 \mu \mathrm{m}$.)

interaction of $T$ pallidum with these extracellular matrices was visualised with phase contrast and scanning electron microscopy. ${ }^{26}$ With each cultured cell type tested, motile organisms attached to the extracellular matrix in a way identical to that previously described for intact cultured cells. ${ }^{3423}$ Figure $1(c)$ is an electron micrograph showing treponemes attached to the residual extracellular matrix from rabbit testicular cells.

The above observations prompted further investigation of treponemal attachment to individual 
components of basement membranes and extracellular matrices. Coverslips were coated with fibronectin at $0,100,200$, and $300 \mathrm{mg} / \mathrm{l}$ for two hours. Treponemes were added and the numbers attached after incubation for $1,5 \frac{1}{2}$, and 16 hours were counted. Table I gives the mean results of three experiments showing treponemal attachment to

TABLE I Attachment of treponemes to coverslips coated with fibronectin for two hours then washed with PBS

\begin{tabular}{lllll}
\hline & \multicolumn{4}{l}{ Mean $(S E M) *$ treponemes/field $(\times 400)$ attached } \\
\cline { 2 - 5 } & \multicolumn{5}{c}{ Concentrations of fibronectin: } \\
\cline { 2 - 5 } $\begin{array}{l}\text { Incubated } \\
\text { (hours) }\end{array}$ & $\begin{array}{l}\text { PBS } \\
\text { (control) }\end{array}$ & $100 \mathrm{mg} / \mathrm{l}$ & $200 \mathrm{mg} / \mathrm{l}$ & $300 \mathrm{mg} / \mathrm{l}$ \\
\hline 1 & $0.4(0 \cdot 3)$ & $1 \cdot 7(0 \cdot 4)$ & $2 \cdot 3(0 \cdot 7)$ & $4 \cdot 2(0 \cdot 7)$ \\
$51 / 2$ & $3 \cdot 3(1 \cdot 4)$ & $7 \cdot 2(2 \cdot 9)$ & $18 \cdot 3(2 \cdot 2)$ & $61 \cdot 7(4 \cdot 4)$ \\
16 & $4 \cdot 3(2 \cdot 4)$ & $15 \cdot 3(7 \cdot 4)$ & $50 \cdot 0(15 \cdot 3)$ & $92 \cdot 5(26 \cdot 5)$ \\
\hline
\end{tabular}

*Mean (SEM) of three separate experiments.

PBS = phosphate buffered saline.

fibronectin. Numbers of attached organisms increased with increasing concentrations and with time of incubation. After 16 hours, coverslips coated with fibronectin at 100,200 , and $300 \mathrm{mg} / \mathrm{l}$ contained $15 \cdot 3,50$, and $92 \cdot 5$ treponemes/field respectively. In contrast, control coverslips coated with PBS contained only 4.3 treponemes/field. As an additional control, coverslips were coated with $2 \%$ bovine serum albumin. Numbers of treponemes attached were identical to those with the PBS control.

Similar experiments were performed with coverslips coated for two hours with laminin at $0,10,25$, and $50 \mathrm{mg} / \mathrm{l}$. Numbers of attached organisms were assessed after $1 \frac{1}{2}, 51 / 2$, and $181 / 2$ hours. Table II presents the mean results of three experiments showing treponemal attachment to laminin. After $51 / 2$ hours, coverslips coated with laminin at 10,25 , and $50 \mathrm{mg} / \mathrm{l}$ contained $49 \cdot 3,121$, and 142 organisms/field respectively. In contrast, control coverslips contained only $\mathbf{2 \cdot 0}$ organisms/field. After $18 \frac{1}{2}$ hours, the numbers of attached treponemes on
TABLE II Attachment of treponemes to coverslips coated with laminin for two hours then washed with PBS

\begin{tabular}{lllll}
\hline & \multicolumn{4}{c}{ Mean $(S E M) *$ treponemes/field $(\times 400)$ attached } \\
\cline { 2 - 5 } & \multicolumn{5}{c}{ Concentrations of laminin: } \\
\cline { 2 - 5 } $\begin{array}{l}\text { Incubated } \\
\text { (hours) }\end{array}$ & $\begin{array}{l}\text { PBS } \\
\text { (control) }\end{array}$ & $10 \mathrm{mg} / \mathrm{l}$ & $25 \mathrm{mg} / \mathrm{l}$ & $50 \mathrm{mg} / \mathrm{l}$ \\
\hline 1 & $1 \cdot 0(0)$ & $27 \cdot 5(11)$ & $17 \cdot 7(3 \cdot 7)$ & $45 \cdot 0(10 \cdot 4)$ \\
$51 / 2$ & $2 \cdot 0(1)$ & $49 \cdot 3(27 \cdot 6)$ & $121 \cdot 0(18)$ & $142 \cdot 0(32 \cdot 4)$ \\
$181 / 2$ & $3.3(1 \cdot 2)$ & $150.0(28 \cdot 9)$ & $200 \cdot 0(10 \cdot 6)$ & $108 \cdot 3(8 \cdot 3)$ \\
\hline
\end{tabular}

* Mean (SEM) of three separate experiments.

PBS = phosphate buffered saline.

laminin coated coverslips sharply increased at the two lower concentrations and decreased at the highest concentration.

In all further experiments the method of coating was altered and the components were air dried on to coverslips. Collagen IV, collagen I, and hyaluronic acid were tested at a range of different concentrations. Best results were found using 100, 200, and $300 \mathrm{mg} / \mathrm{l}$. Tables III and IV summarise nine separate experiments that show treponemal attachment to collagen IV, collagen I, and hyaluronic acid. For each component, numbers of attached organisms increased with increasing concentrations and with time of incubation.

Heat inactivation of $T$ pallidum greatly reduces its ability to attach to cultured cells ${ }^{3}$ and to isolated

TABLE IV Attachment of treponemes to coverslips coated with $50 \mu l$ hyaluronic acid and then air dried

\begin{tabular}{|c|c|c|c|c|}
\hline \multirow{3}{*}{$\begin{array}{l}\text { Incubated } \\
\text { (hours) }\end{array}$} & \multicolumn{4}{|c|}{ Mean $(S E M) *$ treponemes $/$ field $(\times 400)$ attached } \\
\hline & \multirow{2}{*}{$\begin{array}{l}\text { PBS } \\
\text { (control) }\end{array}$} & \multicolumn{3}{|c|}{ Hyaluronic acid concentrations: } \\
\hline & & $100 \mathrm{mg} / \mathrm{l}$ & $200 \mathrm{mg} / \mathrm{l}$ & $300 \mathrm{mg} / \mathrm{l}$ \\
\hline $\begin{array}{l}1 \\
51 / 2\end{array}$ & $\begin{array}{r}3 \cdot 1(0 \cdot 9) \\
5 \cdot 7(1 \cdot 7) \\
11 \cdot 7(0 \cdot 7)\end{array}$ & $\begin{array}{r}5 \cdot 7(0 \cdot 9) \\
18 \cdot 3(2 \cdot 2) \\
33 \cdot 3(4 \cdot 4)\end{array}$ & $\begin{array}{r}8 \cdot 0(0 \cdot 5) \\
20 \cdot 8(2 \cdot 2) \\
53 \cdot 3(6 \cdot 7)\end{array}$ & $\begin{array}{r}9 \cdot 2(0 \cdot 8) \\
26 \cdot 7(3 \cdot 3) \\
70 \cdot 0(7 \cdot 6)\end{array}$ \\
\hline
\end{tabular}

*Mean (SEM) of three separate experiments.

$\mathrm{PBS}=$ phosphate buffered saline.

TABLE III Attachment of treponemes to coverslips coated with $50 \mu$ collagen IV or collagen I and air dried

\begin{tabular}{|c|c|c|c|c|c|c|c|}
\hline \multirow[b]{3}{*}{$\begin{array}{l}\text { Incubated } \\
\text { (hours) }\end{array}$} & \multicolumn{7}{|c|}{ Mean $(S E M) *$ treponemes $/$ field $(\times 400)$ attached } \\
\hline & \multirow[b]{2}{*}{$\begin{array}{l}\text { PBS } \\
\text { control }\end{array}$} & \multicolumn{3}{|c|}{ Concentrations of collagen IV: } & \multicolumn{3}{|c|}{ Concentrations of collagen $\mathrm{I}$ : } \\
\hline & & $100 \mathrm{mg} / \mathrm{l}$ & $200 \mathrm{mg} / \mathrm{l}$ & $300 \mathrm{mg} / \mathrm{l}$ & $100 \mathrm{mg} / \mathrm{l}$ & $200 \mathrm{mg} / \mathrm{l}$ & $300 \mathrm{mg} / \mathrm{l}$ \\
\hline $\begin{array}{l}1 \\
51 / 2 \\
18\end{array}$ & $\begin{array}{l}1 \cdot 3(0 \cdot 3) \\
1 \cdot 3(0 \cdot 3) \\
5 \cdot 3(2 \cdot 6)\end{array}$ & $\begin{array}{cl}1 \cdot 0 & (0) \\
2 \cdot 3 & (0 \cdot 7) \\
37 \cdot 5(11 \cdot 4)\end{array}$ & $\begin{array}{cl}1 \cdot 0 & (0) \\
2 \cdot 3 & (1) \\
40 \cdot 8(19 \cdot 7)\end{array}$ & $\begin{array}{r}1 \cdot 0 \quad(1) \\
3 \cdot 0 \quad(2) \\
75 \cdot 0(18)\end{array}$ & $\begin{aligned} 6 \cdot 8 & (5 \cdot 3) \\
33 \cdot 3 & (5 \cdot 5) \\
60 \cdot 0 & (10)\end{aligned}$ & $\begin{array}{r}5 \cdot 2(3 \cdot 7) \\
37.5(13 \cdot 8) \\
85.0(8 \cdot 7)\end{array}$ & $\begin{array}{r}7 \cdot 7(2 \cdot 1) \\
65 \cdot 0(12 \cdot 2) \\
120 \cdot 0(40 \cdot 4)\end{array}$ \\
\hline
\end{tabular}

*Mean (SEM) of three separate experiments.

$\mathrm{PBS}=$ phosphate buffered saline. 
capillaries, ${ }^{24}$ suggesting that attachment cannot be attributed to passive sticking. Experiments were performed to determine whether heat inactivation would also decrease treponemal attachment to each of the five components. Fibronectin $(62 \mathrm{mg} / \mathrm{l})$, laminin $(10 \mathrm{mg} / \mathrm{l})$, collagen IV (100 mg/l), collagen I $(100 \mathrm{mg} / \mathrm{l})$, and hyaluronic acid $(100 \mathrm{mg} / \mathrm{l})$ were air dried on to coverslips. Viable or heated treponemes were added to the coated coverslips and attachment was assessed after 18 hours. As shown in Table V, on the basis of three experiments heating greatly

TABLE V Attachment of viable versus heat inactivated treponemes to coverslips coated with $50 \mu$ l of components and air dried

\begin{tabular}{llr}
\hline & \multicolumn{2}{l}{$\begin{array}{l}\text { Mean }(S E M) * \\
\text { treponemes } / \text { field }(\times 400) \\
\text { attached after incubation for } \\
\text { I8 hours }\end{array}$} \\
\cline { 2 - 3 } & $\begin{array}{l}\text { Viable } \\
\text { treponemes }\end{array}$ & \multicolumn{1}{l}{$\begin{array}{l}\text { Heated } \\
\text { treponemes }\end{array}$} \\
Component & $10 \cdot 1(0 \cdot 8)$ & $7 \cdot 2(1 \cdot 4)$ \\
PBS (control) & $83 \cdot 3(3 \cdot 3)$ & $10 \cdot 0(1 \cdot 4)$ \\
Fibronectin $(62 \mathrm{mg} / \mathrm{l})$ & $40 \cdot 0(5 \cdot 0)$ & $11 \cdot 7(3 \cdot 1)$ \\
Laminin $(10 \mathrm{mg} / \mathrm{l})$ & $18 \cdot 3(5 \cdot 5)$ & $7 \cdot 8(1 \cdot 7)$ \\
Collagen IV $(100 \mathrm{mg} / \mathrm{l})$ & $44 \cdot 2(16 \cdot 2)$ & $6 \cdot 5(1 \cdot 8)$ \\
Collagen I $(100 \mathrm{mg} / \mathrm{l})$ & $32 \cdot 8(4 \cdot 3)$ & $8 \cdot 6(1 \cdot 2)$ \\
Hyaluronic acid $(100 \mathrm{mg} / \mathrm{l})$ &
\end{tabular}

* Mean (SEM) of three separate experiments.

PBS = phosphate buffered saline.

diminished treponemal attachment to each component. Note the differences in binding of viable organisms to fibronectin and laminin relative to the findings for similar times in Tables I and II. This probably reflects the different coating methods. In experiments summarised in the first two tables fibronectin and laminin were added in solution for two hours and then washed away. In experiments summarised in Table $\mathrm{V}$ the components were air dried on to coverslips.

Factors in immune rabbit serum block treponemal attachment to cultured cells. ${ }^{47}$ To show that immunoglobulin is the active blocking factor, the IgG fractions from normal and immune rabbit serum were purified using affinity chromatography. After pre-incubating organisms with the IgG preparations for 18 hours, motility in both preparations remained above $80 \%$. These two preparations of pretreated organisms were then added to cultured rabbit testicular cells. After incubation for two hours, numbers of attached organisms were counted. As shown in Table VI, in four separate experiments the IgG from immune rabbit serum reduced treponemal attachment. In the normal rabbit serum preparations, $17 \cdot 5$ organisms/cell were attached compared with 2.4 organisms/cell in the immune rabbit serum preparations. The percent blockage $(86 \%)$ compares
TABLE VI Attachment of treponemes to cultured cells after pre-incubation with IgG from normal versus immune rabbit serum

\begin{tabular}{lll}
\hline & \multicolumn{2}{l}{$\begin{array}{l}\text { Treponemes/cultured cell attached after } \\
\text { incubation for two hours }\end{array}$} \\
\cline { 2 - 3 } & $\begin{array}{l}\text { Normal rabbit } \\
\text { serum IgG }\end{array}$ & $\begin{array}{l}\text { Immune rabbit } \\
\text { serum IgG }\end{array}$ \\
\hline 1 & $17 \cdot 5$ & $3 \cdot 0$ \\
2 & $4 \cdot 8$ & $1 \cdot 1$ \\
3 & $25 \cdot 5$ & $2 \cdot 8$ \\
4 & $22 \cdot 1$ & $2 \cdot 7$ \\
Average (SEM) & $17 \cdot 5(4 \cdot 5)$ & $2 \cdot 4(0 \cdot 7)$ \\
\hline
\end{tabular}

favourably with that previously reported using whole serum instead of the IgG fractions.?

Experiments were then performed to determine whether whole serum from immune rabbits would block treponemal attachment to the five tissue components. Treponemes were preincubated for 18 hours in normal or immune rabbit serum; motility in both groups remained above $90 \%$. Fibronectin $(62 \mathrm{mg} / \mathrm{l})$, laminin $(10 \mathrm{mg} / \mathrm{l})$, collagen IV $(100 \mathrm{mg} / \mathrm{l})$, collagen I $(100 \mathrm{mg} / \mathrm{l})$, and hyaluronic acid $(200 \mathrm{mg} / \mathrm{l})$ were air dried on to coverslips. The pretreated organisms were then added to the chambers. The numbers attached were counted after incubation for two hours. The mean results of three experiments, shown in Table VII, clearly indicate that factors present in immune rabbit serum blocked treponemal attachment to four of the tissue components (73-92\% blockage). Attachment to hyaluronic acid, however, was not affected.

Similar experiments were performed using the IgG fractions of normal or immune rabbit serum. After pre-incubation of treponemes with non-immune or immune IgG for 18 hours, motilities in both suspensions remained above $80 \%$. These two suspensions were then added to coverslips coated with fibronectin (62 mg/l), laminin (10 mg/l), collagen IV (100 mg/l),

TABLE VII Attachment of treponemes to coverslips coated with $50 \mu$ l of components and air dried after pre-incubation with normal versus immune rabbit serum

\begin{tabular}{lll}
\hline & \multicolumn{2}{c}{$\begin{array}{l}\text { Mean }(S E M) \text { treponemes/field } \\
(\times 400) \text { attached after incubation } \\
\text { for two hours }\end{array}$} \\
\cline { 2 - 3 } & $\begin{array}{l}\text { Normal } \\
\text { rabbit serum }\end{array}$ & $\begin{array}{l}\text { Immune } \\
\text { rabbit serum }\end{array}$ \\
& $3 \cdot 7(1 \cdot 0)$ & $1 \cdot 0(0 \cdot 3)$ \\
Component & $51 \cdot 7(6 \cdot 0)$ & $3 \cdot 6(0 \cdot 8)$ \\
PBS (control) & $23 \cdot 3(6 \cdot 6)$ & $3 \cdot 2(1 \cdot 0)$ \\
Fibronectin $(62 \mathrm{mg} / 1)$ & $9 \cdot 8(3 \cdot 0)$ & $1 \cdot 3(0 \cdot 3)$ \\
Laminin $(10 \mathrm{mg} / 1)$ & $22 \cdot 2(6 \cdot 2)$ & $5 \cdot 7(2 \cdot 2)$ \\
Collagen IV $(100 \mathrm{mg} / 1)$ & $4 \cdot 0(0 \cdot 3)$ & $4 \cdot 0(0 \cdot 4)$ \\
Collagen I $(100 \mathrm{mg} / 1)$ & & \\
Hyaluronic acid $(100 \mathrm{mg} / 1)$ & &
\end{tabular}

* Mean (SEM) of three separate experiments.

PBS = phosphate buffered saline. 
or collagen I ( $100 \mathrm{mg} / \mathrm{l})$; hyaluronic acid was not tested. After incubation for two hours, attached treponemes were counted. The mean results of four experiments are shown in Table VIII. The IgG from immune rabbit serum inhibited treponemal attach-

TABLE VIII Attachment of treponemes to coverslips coated with $50 \mu$ l of components and air dried after pre-incubation with IgG from normal versus immune rabbit serum

\begin{tabular}{|c|c|c|}
\hline \multirow[b]{2}{*}{ Component } & \multicolumn{2}{|c|}{$\begin{array}{l}\text { Mean }(S E M) * \text { treponemes } / \text { field } \\
(\times 400) \text { attached after incubation } \\
\text { for two hours }\end{array}$} \\
\hline & $\begin{array}{l}\text { Normal rabbit } \\
\text { serum IgG }\end{array}$ & $\begin{array}{l}\text { Immune rabbit } \\
\text { serum IgG }\end{array}$ \\
\hline $\begin{array}{l}\text { PBS (control) } \\
\text { Fibronectin }(62 \mathrm{mg} / \mathrm{l}) \\
\text { Laminin }(10 \mathrm{mg} / \mathrm{l}) \\
\text { Collagen IV }(100 \mathrm{mg} / \mathrm{l}) \\
\text { Collagen I }(100 \mathrm{mg} / \mathrm{l})\end{array}$ & $\begin{array}{l}3 \cdot 2(0 \cdot 4) \\
11 \cdot 1(3 \cdot 0) \\
15 \cdot 0(2 \cdot 7) \\
2 \cdot 0(0) \\
5 \cdot 7(2 \cdot 3)\end{array}$ & $\begin{array}{l}1 \cdot 2(0 \cdot 3) \\
2 \cdot 9(0 \cdot 7) \\
6 \cdot 5(2 \cdot 0) \\
0 \cdot 7(0 \cdot 2) \\
2 \cdot 8(1 \cdot 8)\end{array}$ \\
\hline
\end{tabular}

*Mean (SEM) of four separate experiments.

$\mathrm{PBS}=$ phosphate buffered serum.

ment to each of the four components (50-72\% blockage). Note the differences in numbers of attached $T$ pallidum relative to those in Table VII. This probably reflects the different serum concentrations within the suspending medium. In experiments summarised in Table VII treponemes were suspended in $55 \%$ rabbit serum as opposed to $5 \%$ rabbit serum in those summarised in Table VIII. Also, note the differences in attached organisms listed in Tables I-IV, VII, and VIII. The increased attachment may be associated with the preincubation of 18 hours used for experiments summarised in the last two tables. This preincubation is known to alter the treponemal outer surface, making it more susceptible to antibody reactions. The altered surfaces in turn may facilitate better attachment to the five tissue components.

\section{Discussion}

The findings presented in this paper show the in vitro adherence of $T$ pallidum to fibronectin, laminin, collagen IV, collagen I, and hyaluronic acid. Each of these components is inherently "sticky" and the question arises as to the importance of this treponemal attachment. Three observations suggest that this binding is at least somewhat specific. Firstly, compared with viable treponemes heat inactivated organisms attached poorly to each substrate. If the treponemes were adhering passively the heated organisms should have attached just as well as the viable organisms. Secondly, treponemal attachment to cultured cells ${ }^{325}$ or capillaries ${ }^{24}$ is mediated at one end, indicating that the attachment ligands are localised at one tip of $T$ pallidum. In a similar way, treponemes attached to fibronectin, laminin, collagen IV, collagen I, and hyaluronic acid at one end. If the binding to these substrates reflected passive adherence, organisms should have attached both at their tips and along the entire length of their surfaces. Thirdly, the IgG of immune rabbit serum inhibited treponemal attachment to fibronectin, laminin, collagen IV, and collagen I. This inhibition may be attributed to the presence of antibodies to the treponemal ligands for these four components. It is also possible that the IgG by binding to other treponemal surface antigens may stereochemically hinder ligand attachment or, alternatively, that these antibodies interfere with active metabolism, which in turn is necessary for attachment.

Bacterial attachment in some cases results from complex interactions. Streptococcus mutans attaches to oral tissues via proteins, glycoproteins, and carbohydrates. ${ }^{27} 28$ Escherichia coli attaches to urinary epithelial cells in a two step process: long range attachment occurs through adhesins in pili and short range attachment through adhesins in the outer cell walls. ${ }^{29}$ It is becoming apparent that the mechanisms of treponemal attachment are also complex. Carbohydrates are partly implicated as shown by reduced attachment to cultured cells pretreated with hyaluronidase ${ }^{30}$ or periodate. ${ }^{31}$ Fibronectin may also be associated with attachment. We have shown in preliminary studies that this component is associated with the surface of $T$ pallidum, and that preincubation with antifibronectin partly blocks attachment to cultured cells. In addition, trypsin degrades fibronectin, and pretreatment of $T$ pallidum with this enzyme subsequently reduced its ability to attach to cells. ${ }^{32}$ Furthermore, once organisms have attached to cultured cells, trypsinisation effectively removes them. ${ }^{33}$

Baseman and Hayes have suggested that treponemes attach to cultured cells via three treponemal ligand proteins ${ }^{32}$; antibodies to these proteins have been detected in immune rabbit serum. In this study we observed that IgG in immune rabbit serum blocked treponemal attachment to fibronectin, laminin, collagen IV, and collagen I. The three protein ligands of Baseman and Hayes ${ }^{32}$ may conceivably involve the treponemal ligands for one or more of these four substrates. A recently published paper in fact indicates that at least one of these ligands binds to fibronectin. ${ }^{34}$

As shown by phase contrast and scanning electron microscopy, $T$ pallidum attached to the extracellular matrix of cultured cells and to isolated basement membranes of retinal and kidney tissue. Fibronectin, collagen I, and hyaluronic acid are present in vivo within extracellular matrices; fibronectin, laminin, and collagen IV are present within basement membranes. After treponemes initially enter the 
host, as well as immediately disseminating they also localise at the site of entry producing the primary lesion. If all of the organisms bound to the fibronectin, collagen $\mathbf{I}$, or hyaluronic acid within the extracellular matrix, they would be unable to make their way through this matrix, reach the vascular basement membrane, and disseminate. Turner and Hollander have shown that within two hours, $10 \%$ of the inoculated organisms were localised within the testicular tissue and the other $90 \%$ had disseminated to other tissues. ${ }^{35}$ The findings presented in this paper may partly explain this enigma of localisation versus dissemination. We suggest that $T$ pallidum has heterogenous attachment abilities. One population may bind to fibronectin, collagen I, or hyaluronic acid; these organisms could localise within the extracellular matrix at the site of entry. A second population may bind to laminin and collagen IV; these organisms could bind to vascular basement membranes, penetrate, and then disseminate to other tissues. We are currently exploring this possibility, and preliminary findings have indicated that different populations of $T$ pallidum do occur, some of which cannot bind to fibronectin.

We thank Anne Utyro for her expert technical help. This research was supported by Public Health Service, National Institute of Allergy and Infectious Diseases grants AI 16585 and AI 12601 and by the World Health Organization grant V3/181/26.

\section{References}

1. Savage DC Survival on mucosal epithelia, epithelial penetration and growth in tissues of pathogenic bacteria. Symposia of the Society for General Microbiology 1972;22: 25-57.

2. Fitzgerald TJ. Pathogenesis and immunology of Treponema pallidum. Annu Rev Microbiol 1981;35:29-54.

3. Fitzgerald TJ, Miller JN, Sykes JA. Treponema pallidum (Nichols strain) in tissue cultures: cellular attachment, entry, and survival. Infect Immun 1975;11:1133-40.

4. Hayes NS, Muse KE, Collier AM, Baseman JB. Parasitism of virulent Treponema pallidum of host cell surfaces. Infect Immun 1977; 17: 174-86.

5. Wright MI. Exploratory studies in tissue culture of $T$ pallidum. Proceedings of the 12th International Congress of Dermatology 1962; 2:884-7.

6. Fieldsteel AH, Stout JG, Becker FA. Comparative behavior of virulent strains of Treponema pallidum and Treponema pertenue in gradient cultures of various mammalian cells. Infect Immun 1979; 24: 337-45.

7. Fitzgerald TJ, Johnson RC, Miller JN, Sykes JA. Characterization of the attachment of Treponema pallidum (Nichols strain) to cultured mammalian cells and the potential relationship of attachment to pathogenicity. Infect Immun 1977; 18:467-78.

8. Foldvart JM, Bere EW, Yaar M, Rennard SI, Gullino M, Martin GR, Katz SI. Distribution and immunoelectron microscopic localization of laminin, a non-collagenous basement membrane glycoprotein. Lab Invest 1980; 42:336-42.

9. Repesh LA, Furcht LT, Smith D. Immunocytochemical localization of fibronectin in limb tissues of the adult newt. $J$ Histochem Cytochem 1981;29:937-45.
10. Templ R, Bruckner P, Fietzek P. Immunocytochemical study of basement membrane (type IV) collagens. Immunology 1979; 38: $109-16$.

11. Vaheri A. Alitalo K. Pericellular matrix glycoproteins in cell differentiation and in malignant transformation. In: Lloyd CW, Rees DA, eds. Cellular controls in differentiation. New York: Academic Press, 1982: 29-56.

12. Culp LA, Rollins BJ, Buniel J. Kitri S. Two functionally distinct pools of glycosaminoglycans in the substrate adhesion site of murine cells. $J$ Cell Biol 1978; 79:788-801.

13. Lehto VP, Vartio T, Virtanen I. Fibronectin remains in the cytoskeletal preparations of cultured human fibroblasts. Cell Biol Int Rep 1981;5:417-26.

14. Terranova VP, Liotta LA, Russo RG, Martin GR. Role of laminin in the attachment and metastasis of murine tumor cells. Cancer Res 1982;42:2265-9.

15. Yamada KM, Olden K. Fibronectins-adhesive glycoproteins of cell surface and blood. Nature 1978; 275: 179-84.

16. Kuusela P. Fibronectin binds to Staphylococcus aureus. Nature 1978; 276:718-20.

17. Beachey EH, Simpson WA. The adherence of group A streptococci to oropharyngeal cells: the lipoteichoic acid adhesion and fibronectin receptor. Infection 1982; 10:107-11.

18. Myhre EB, Kuusela P. Binding of human fibronectin to groups $A, C$, and $G$ streptococci. Infect Immun 1983;40:29-34.

19. Segal E, Kerk KS, Calderone R, Scheld WM. The role of fibronectin in the attachment of Candida albicans to human cells. Clinical Research 1982; 30:378A.

20. Grinnel F, Feld MK. Initial adhesion of human fibroblasts in serum-free medium: possible role of secreted fibronectin. Cell 1979; 17: 117-29.

21. Klebe RJ. Isolation of a collagen-dependent cell attachment factor. Nature 1974; 250:248-51

22. Murray JC, Liotta L, Rennard S, Martin GR. Adhesion characteristics of murine metastatic and non-metastatic tumor cells in vitro. Cancer Res 1980;40:347-51.

23. Sykes JA, Moore EB. A simple tissue culture chamber. Tex Rep Biol Med 1960;18:288-97.

24. Quist EE, Repesh LA, Zeleznikar R, Fitzgerald TJ. Interaction of Treponema pallidum with isolated rabbit capillary tissues. Br J Vener Dis 1983; 59: 11-20.

25. Fitzgerald TJ, Cleveland P, Johnson RC, Miller JN, Sykes JA Scanning electron microscopy of Treponema pallidum (Nichols strain) attached to cultured mammalian cells. J Bacteriol 1977; 130: 1333-44.

26. Fitzgerald TJ, Repesh LA, Oakes SG. Morphological destruction of cultured cells by the attachment of Treponema pallidum. Br J Vener Dis 1982;58: 1-11.

27. Staat RH, Langley SD, Doyle RJ. Streptococcus mutans adherence: presumptive evidence for protein-mediated attachment followed by glucan-dependent cellular accumulation. Infect Immun 1980; 27:675-81.

28. Wu-Yaun CD, Tai S, Slade HD. Properties of Streptococcus mutans grown in synthetic medium: binding of glycosyltransferase and in vitro adherence, and binding of dextran/glucan and glycoprotein and agglutination. Infect Immun 1979;23: 600-8.

29. Eshdat Y, Speth V, Jann K. Participation of pili and cell wall adhesin in the yeast agglutination activity of Escherichia coli. Infect Immun 1981;34:980-6.

30. Fitzgerald TJ, Johnson RC, Ritzi DM. Relationship of Treponema pallidum to acidic mucopolysaccharides. Infect Immun 1979;24:252-60.

31. Alderete JF, Baseman JB. Surface characterization of virulent Treponema pallidum. Infect Immun 1980;30:814-23.

32. Baseman JB, Hayes EC. Molecular characterization of receptor binding proteins and immunogens of virulent Treponema pallidum. J Exp Med 1980; 151:573-86.

33. Fieldsteel AH, Cox DL, Moeckli RA. Cultivation of virulent Treponema pallidum in tissue culture. Infect Immun 1981;32: 908-15.

34. Peterson KM, Baseman JB, Alderete JF. Treponema pallidum receptor binding proteins interact with fibronectin. J Exp Med 1983; 157: 1958-70.

35. Turner TB, Hollander DH. Biology of the treponematoses. WHO Monogr Ser 1957; No 35. 